\title{
A review of the literature on the prevention of suicide through interventions in Accident and Emergency Departments
}

\author{
JULIE REPPER BA, MPhil, RMN, RGN \\ Research Student, University of Manchester, Manchester M13 9PL, UK \\ Accepted for publication 4 November 1997
}

\section{Summary}

- In order to inform the development of a specialist 'suicide prevention nurse' to work in an Accident and Emergency department (A\&E), a review of literature in the area was undertaken.

- Priority was given to papers describing well specified interventions with a carefully defined client group. Only eight such studies were identified and, although they do have clear implications for practice, they provide inadequate information regarding the targeting of all clients at risk of suicide.

- The review was therefore broadened to include all UK literature on suicide and parasuicide at population and individual levels. Three distinct groups of $\mathrm{A} \& \mathrm{E}$ attendees at particular risk of suicide were identified: patients attending A\&E following deliberate self-harm; attendees with specific physical problems, and attendees with a known history of mental health problems.

- The needs of each of these groups are described, with their implications for the role of a 'suicide prevention nurse' in A\&E.

- In conclusion, action to reduce suicide needs to be taken at all levels of the organization and the role of the suicide prevention nurse needs to include support, training and development as well as specific time limited therapy with a highly targeted group of patients at specific risk.

Keymords: nurse, parasuicide, suicide, suicide prevention.

\section{Aim of the review}

This review was undertaken to identify the most useful 'suicide prevention' role for a nurse working in A\&E. Since few studies exist which describe specific suicide reduction interventions in $\mathrm{A} \& \mathrm{E}$ departments, this review draws on the wider literature about suicide and parasuicide at population and individual levels to recommend a series of possible actions which might usefully be undertaken by an individual worker in $\mathrm{A} \& \mathrm{E}$ and by the

Correspondence to: Julie Repper, Research Student, University of Manchester, Manchester M13 9PL, UK. multidisciplinary team/managerial staff working in this area.

\section{SEARCH STRATEGY}

The question addressed by this review is: what interventions in $\mathrm{A} \& \mathrm{E}$ have been effective in reducing suicide in adults? The key words suicide/self-injury, accident and/ or emergency departments/casualty were used to search Medline, CINAHL and the Science Citation Index and identify relevant English language papers reporting studies/reviews undertaken since 1990. This generated several 
hundred abstracts. From this list, all English language papers which indicated specific interventions, trials or evaluated initiatives undertaken in $\mathrm{A} \& \mathrm{E}$ to reduce suicide were obtained. Several further references which had not arisen in the initial searches were cited in these articles; these were subsequently obtained. In addition all UK conference reports and national reports/guidelines on suicide were selected to give a clear picture of the national context, including those about current understanding of suicide and suicide prevention; noteworthy suicide prevention initiatives; ongoing research and suicide prevention in A\&E departments.

\section{TARGETS FOR REDUCING SUICIDE}

Reversal of the rising trends in suicide and attempted suicide in Europe has become one of the World Health Organisation targets for Europe as part of its 'Health for All' strategy and the reduction of suicide is included as a key target in the UK Health of the Nation strategy (DoH, 1992). Suicide reduction is the only quantified aim in the area of psychiatric illness, where the overall purpose is to 'reduce ill health and death caused by mental illness'. The first target is to improve significantly the health and social functioning of mentally ill people; the second, to reduce the overall suicide rate by at least $15 \%$ by the year 2000 (from 11 per 100000 to no more than 9.4 per 100000 ); and the third, to reduce the life time rate of suicide in people with severe mental illness by at least one third from the Health of the Nation (DoH, 1992) estimate of $15 \%$ in 1990 to no more than $10 \%$ by the year 2000 .

There appears, however, to be no conclusive evidence that the Health of the Nation suicide reduction targets are, in fact, achievable. Indeed, the use of suicide rates as an outcome indicator in psychiatry has been criticized. Firstly, due to the obvious difficulty of demonstrating the effectiveness of a local intervention strategy when suicide occurs so rarely, giving very small numbers of suicides amongst people with serious mental health problems (Gunnell, 1994a). Secondly, such small numbers as do exist locally are problematic owing to coroners' differential interpretations of the law (Williams \& Morgan, 1994). Thirdly, suicide rates are clearly influenced by factors outside health service control such as access to an effective means of committing suicide, divorce rates and employment levels (Charlton et al., 1992) - suicide levels may therefore reflect changes in these factors rather than the success of any health service intervention. However, the stability of differences between European countries since World War Two (with Hungary, Denmark and Finland having the highest rates and the UK having a relatively low rate) suggest that suicide rates are not amenable to great change as a result of specific interventions.

\section{PARASUICIDE AND ATTEMPTED SUICIDE}

Attempted suicide and parasuicide have been defined in different ways. The World Health Organisation (1982) defines both as non-habitual acts with a non-fatal outcome, deliberately initiated and performed by the person involved. However, unlike attempted suicide, parasuicide is defined as intentionally non-fatal. Since it is frequently difficult to differentiate between these two groups in practice, it is not surprising that it is also difficult to distinguish reliably between them in reports. Therefore, for the purpose of this review, people who attempted suicide or parasuicide will be considered as one group and referred to as those who 'deliberately self-harm' (DSH). Concentration on suicide death distorts the understanding of suicide: people who have committed non-fatal acts of deliberate self-harm are at greatly increased risk of committing suicide at some later date. There are clear demographic differences between DSH and suicide: the former is more frequent in younger age groups and in females and drug overdose is more frequent in DSH $(87 \%)$ than in suicide $(24 \%)$. Thirty to forty-seven per cent of suicides have a history of $\mathrm{DSH}$, in the year following DSH about 1\% kill themselves (100 times the rate expected in the general population), and in the subsequent 10 years between 3 and $10 \%$ may do so. Within the overall population of DSH patients, established risk factors which correlate with eventual suicide are male sex, membership of social class $\mathrm{V}$, unemployment, previous deliberate self-harm, substance abuse, previous psychiatric admission (Williams \& Morgan, 1994).

\section{PREDICTING SUICIDE}

The process of assessing the risk of suicide involves matching the individual with a set of risk factors which have been shown to correlate positively with increased suicide. Several studies have tried to identify predictors of suicide after attempted suicide. Hawton \& Fagg (1982), Nordentoft et al. (1993) and Williams \& Morgan (1994) conclude that socio-demographic and individual factors which are associated with an increased risk of suicide include: being elderly, male, single/divorced or widowed, unemployed or retired, living alone, physical illness especially terminal, painful or debilitating - history of deliberate self-harm, family history of affective disorder, alcoholism or suicide, bereavement in childhood, membership of social classes I or V, psychiatric and personality 
disorders. Other social influences include recent loss of status or humiliation, and the role of imitation - which has been found to have more influence on the means of committing suicide or self-harming than on the overall rate. Certain occupational groups which offer access to a means of suicide and are associated with stress and isolation are particularly at risk: in farmers the suicide rate is 1.5-2 times that of the general population. Other occupational groups at increased risk include doctors, veterinary surgeons, pharmacists and dentists. Records of contact with health professionals by people who commit suicide demonstrate an interesting paradox: around $40 \%$ have contact with a health professional in the month before death and $25 \%$ in the week before death, yet people committing suicide also have the lowest rate of GP consultation generally (Morgan \& Priest, 1991; Vassilas \& Morgan, 1993; Gunnell, 1994a).

These findings have emerged primarily from large control, cohort and case studies of individuals who have committed suicide but such a list is unspecified and insensitive: the relative weightings of any of these factors will vary from person to person and it is essential that each individual's situation and current response is assessed fully. Several studies have sought to construct instruments which combine indicators to give a more accurate prediction of risk. Pallis et al. (1982) combined clinical information on symptoms with information about circumstances of the attempts and demographic information. They found that good discriminators included behavioural retardation (more common in completed suicides), anger, fatigue and a row in the previous $48 \mathrm{~h}$ (more common in attempted suicides). On retrospective analysis of a sample of 75 suicides and 146 attempted suicides, their combined scale assigned $91 \%$ completed suicides and $83 \%$ attempted suicides to the correct group. Pokorney (1983) constructed a scale of clinical and demographic indicators which was used with 4800 consecutive admissions to a Veterans Administration Hospital in the US. Many items with good correlation with completed suicides were reported but overall the usefulness of the scale was limited by the high number of false positives produced. It might, however, be argued that in a prospective study such as this raising awareness of the likelihood of suicide would have led to some kind of intervention: false positives are preferable to missed cases.

\section{THE ASSESSMENT OF SUICIDE RISK}

Despite the availability of standardized risk assessment tools, Rice \& Donnelly (1991) reported a very small number of clinicians actually using these tools. They gave several reasons for this: some instruments are designed for research rather than for clinical practice; they often require extensive training to be used competently; and they do not inform clinical decision making and are time consuming. Yet the fact that many people who go on to commit suicide have had contact with health care professionals shortly before their death is evidence of the difficulty of assessing suicide risk in routine clinical practice. Several studies report that, even where patients have expressed hopelessness or suicidal thoughts, clinicians have not taken action to determine or prevent intent (Goh et al., 1989; Morgan \& Priest, 1991).

Morgan (1994) describes the hazards of assessing suicide risk as lying in the variety of behaviours that may be exhibited by a suicidal person. Although depression is linked with suicide, suicidal patients may not present as depressed, retarded and self-blaming: they may be angry and challenging. They may have become alienated from the staff caring for them - particularly when their symptoms or threats of suicide recur, these people may be viewed as insincere or unnecessarily dependent on the support of others. A further problem is the fluctuating nature of suicidal ideation: intent may vary even within a single day and staff may be reassured by patients who are feeling temporarily more hopeful. Other patients who are determined to end their lives may deliberately set out to reassure staff so that they can gain the freedom to kill themselves.

Williams \& Morgan (1994) provide clear guidelines for the assessment of suicide risk in routine clinical practice. They emphasize that suicidal ideation varies greatly in its significance of risk from one individual to another so:

... the risk in any individual can only be assessed

effectively by full clinical evaluation consisting of a thorough review of the history and present illness, assessment of mental state and a diagnostic formulation (1994, p. 19).

In a sensitive account of the assessment process they point out the usefulness of considering how it must feel to want to end one's life. Since ambivalence appears to exist until a very late stage in the decision to commit suicide, a positive attitude towards whether life is worth living and whether life is feasible can be crucial in helping a person to decide against suicide. However skillfully an interview is conducted one-off assessments of an individual can be very misleading: the level of suicidal intent varies rapidly and people intent on suicide may deliberately give a false impression. It is therefore essential to interview relatives and others important to the individual to ascertain their impressions of the level of risk, and whether the person has expressed suicidal ideas or behaviour. Indeed, carer 
and family attitudes are important factors in suicide prevention: Pierce (1986) found a significant association between repetition of DSH and the perception of an unsympathetic attitude in the family. One third of his sample of 100 patients believed the family was unsympathetic to their action.

In view of the importance of gaining the trust of the person in order to understand the level of risk and imparting personal hope and a sense of the value of the patient's life, negative attitudes toward suicide can be very damaging. They are, however, widely reported within the literature. Ramon et al. (1975) reported that physicians frequently viewed patients who poisoned themselves as manipulative. Williams \& Morgan (1994) describe negative attitudes lying in misconceptions surrounding the feasibility of suicide prevention: practitioners frequently believe that individuals should be allowed to commit suicide if they wish, and that suicide is often not preventable, but Morgan \& Evans (1995) found that giving information on the incidence, assessment and management and assessment of suicide significantly reduced such negative attitudes.

\section{SUICIDE PREVENTION IN A\&E}

Most research on suicide reduction and prevention in $\mathrm{A} \& \mathrm{E}$ focuses on DSH patients, but these are not the only patients presenting in casualty departments who carry a risk of suicide. Two other broad groups must be considered: those who ostensibly attend with physical injury but who have significant psychiatric morbidity, and those with a known psychiatric diagnosis who attend in crisis for emergency assessment or treatment.

\section{DELIBERATE SELF-HARM (DSH)}

\section{Epidemiology of DSH}

The number of patients attending A\&E with DSH has increased dramatically over the last two decades. Hawton \& Fagg (1988) report a four-fold increase in Oxford between 1963 and 1973, and it is estimated that there are 100000 general hospital referrals for DSH per year $(\mathrm{DoH}$, 1992). Indeed, it has been suggested that DSH is the most common reason for admission to medical wards for women, and the second highest cause of admission for men - after ischaemic heart disease (Williams \& Morgan, 1994). Hawton \& Fagg (1988) studied suicide and other causes of death in a group of nearly 2000 DSH patients. After a mean follow-up of 8 years, $2.8 \%$ had died through suicide or probable suicide $(1 \%$ in the first year after the index attempt), and the death rate from natural causes was
3.3 times higher than would be expected from the age of the group. In a 10-year follow-up study of people who had made an attempt to kill themselves at some time, Nordentoft et al. (1993) reported suicide rates 30 times higher than those expected. Again, in the year following the index act, $1 \%$ killed themselves.

\section{Predicting repeat $D S H$}

Given the association between repeated self-harm and eventual suicide, there is clearly a sound clinical rationale for identifying those at highest risk of repeated attempts for intervention. Buglass \& Horton (1974) suggest that clients who have a history of psychiatric treatment, alcohol related problems, two or more previous admissions for $\mathrm{DSH}$, are not living with a relative, and a diagnosis of sociopathy, have a $50 \%$ chance of a repeated attempt of DSH within 6 months of the last. These criteria have been used in several research studies to identify those at most serious risk of repeat DSH (e.g. Salkovskis et al., 1990). However, their use in clinical practice is limited as they do not identify all those at risk of suicide. Careful assessment of every individual who has harmed themselves is necessary, as discussed in the assessment of suicide risk above. As Morgan (1994) states:

It is unsafe to assume that anyone who talks about suicide is merely threatening and is therefore unlikely to carry it out (p. 49).

The degree of physical harm perpetrated in DSH is also not a reliable guide to the degree of psychological distress. It is therefore essential that all patients attending $\mathrm{A} \& \mathrm{E}$ with DSH are offered a full assessment.

Williams \& Morgan (1994) summarize the reasons for DSH as an attempted solution for relationship problems which are in crisis; a crisis that feels to be beyond the control of the subject; and as a metaphor for problems of hostility, loss and responsibility. It must also be considered that episodes of DSH might carry associated risk for others such as dependants or children. For these reasons, assessment must not be confined to mental state and previous psychiatric history, but must inform the subsequent management of the patient. Therefore a full psychosocial assessment is necessary.

\section{Interventions to reduce repeat DSH and suicide}

A number of studies have evaluated interventions attempting to reduce repeat attempts of DSH and ultimately reduce the likelihood of suicide. The results are generally disappointing (see Table 1); however, they clearly have implications for practice (see Figure 1). It might be 
Table 1 Summary of intervention studies which have attempted to reduce repeated deliberate self-harm (DSH)

\begin{tabular}{|c|c|c|c|c|c|c|}
\hline Authors & Design & Treatment & Clients & Assessment & Findings & Comments \\
\hline $\begin{array}{l}\text { Chowdhury et al. } \\
\text { (1973) }\end{array}$ & $\begin{array}{l}\text { RCT } \\
\text { routine treatment } \\
(n=100) \text { vs } \\
\text { appointments } \\
\text { with psychiatrist }(n=97)\end{array}$ & $\begin{array}{l}\text { Regular appointments } \\
\text { with psychiatrist } \\
\text { at home for } 6 \text { months } \\
\text { Access to } 24 \text { hour } \\
\text { phone contact }\end{array}$ & $\begin{array}{l}\text { DSH clients who had } \\
\text { attempted self harm } \\
\text { at least twice. } \\
\text { High risk clients } \\
\text { excluded }\end{array}$ & $\begin{array}{l}\text { Repeat of self harm } \\
\text { Target problems } \\
\text { Depressive mood } \\
\text { Pre-treatment and } \\
6 \text { month follow-up }\end{array}$ & $\begin{array}{l}\text { No difference in two } \\
\text { groups overall } \\
\text { Women in E group } \\
\text { had solved more } \\
\text { problems and had } \\
\text { less depressed mood }\end{array}$ & $\begin{array}{l}\text { Excluded patients at } \\
\text { high risk of repeated } \\
\text { attempts. More effective } \\
\text { studies deliberately } \\
\text { targeted high } \\
\text { risk clients. }\end{array}$ \\
\hline $\begin{array}{l}\text { Gibbons et al. } \\
(1978)\end{array}$ & $\begin{array}{l}\text { RCT } \\
\text { routine follow-up } \\
(n=200) \\
\text { vs social work } \\
\text { task-centred work } \\
(n=200)\end{array}$ & $\begin{array}{l}\text { Time-limited, } \\
\text { task-centred } \\
\text { problem solving } \\
\text { intervention with } \\
\text { gradual withdrawal } \\
\text { of help. Offered } \\
\text { immediately } \\
\text { and in own home }\end{array}$ & $\begin{array}{l}\text { Self-poisoning } \\
\text { clients not already } \\
\text { receiving active } \\
\text { treatment elsewhere }\end{array}$ & $\begin{array}{l}\text { Repetition of DSH } \\
\text { Service use } \\
\text { Depressive mood } \\
\text { Social problems } \\
\text { Satisfaction with } \\
\text { services Follow-up at } \\
4,12 \text {, and } 18 \text { months }\end{array}$ & $\begin{array}{l}\text { No difference in } \\
\text { repeat DSH. } \\
\text { Both groups } \\
\text { improved in mood } \\
\text { and social problems } \\
\text { E group more change } \\
\text { in social problems } \\
\text { and more satisfied } \\
\text { with service }\end{array}$ & $\begin{array}{l}139 \text { patients excluded } \\
\text { from study as receiving } \\
\text { help elsewhere had } \\
\text { higher levels of } \\
\text { psychiatric and } \\
\text { social disability. }\end{array}$ \\
\hline $\begin{array}{l}\text { Hawton et al. } \\
\text { (1981) }\end{array}$ & $\begin{array}{l}\text { RCT } \\
\text { domicilliary treatment } \\
(n=48) \text { vs } \\
\text { Outpatient treatment } \\
(n=48) \\
\text { by medical and } \\
\text { non-medical practitioners }\end{array}$ & $\begin{array}{l}\text { Brief problem } \\
\text { solving orientated } \\
\text { counselling in home } \\
\text { or out-patients } \\
\text { Medical and } \\
\text { non-medical therapists } \\
\text { worked with clients } \\
\text { Involvement of other } \\
\text { family members }\end{array}$ & $\begin{array}{l}\text { Patients attending } \\
\text { A\&E following } \\
\text { self-poisoning }\end{array}$ & $\begin{array}{l}\text { Suicidal intent, } \\
\text { ideas and repetition } \\
\text { Target problems } \\
\text { Mood } \\
\text { Social adjustment } \\
\text { Pre-treatment } \\
\text { and end of treatment } \\
\text { (approx. } 9 \text { months) } \\
\text { Follow-up for } \\
\text { non-attenders at } \\
\text { one month }\end{array}$ & $\begin{array}{l}\text { No difference between } \\
\mathrm{C} \text { and } \mathrm{E} \text { groups, } \\
\text { nor between medical } \\
\text { and non-medical } \\
\text { therapists } \\
\text { Improvement } \\
\text { in all patients on mood, } \\
\text { social adjustment, } \\
\text { and target problems } \\
\text { Higher attendance } \\
\text { in home treatment }\end{array}$ & $\begin{array}{l}\text { Non-attenders } \\
\text { were from lower } \\
\text { social class and had } \\
\text { more relationship } \\
\text { problems, they had } \\
\text { worse outcome than } \\
\text { those treated in } \\
\text { out-patients }\end{array}$ \\
\hline $\begin{array}{l}\text { Hawton et al. } \\
\text { (1987) }\end{array}$ & $\begin{array}{l}\text { RCT } \\
\text { Brief outpatient } \\
\text { counselling } \\
(n=41) \text { vs } \\
\text { GP care with advice } \\
\text { on management } \\
(n=39)\end{array}$ & $\begin{array}{l}\text { Non-medical } \\
\text { practitioners } \\
\text { offered counselling } \\
\text { based on } \\
\text { supportive problem } \\
\text { solving model } \\
\text { Family members } \\
\text { involved where } \\
\text { appropriate }\end{array}$ & $\begin{array}{l}\text { Overdose patients } \\
\text { not in current } \\
\text { psychiatric care or } \\
\text { requiring intensive } \\
\text { psychiatric treatment }\end{array}$ & $\begin{array}{l}\text { Suicidal intent } \\
\text { and risk of } \\
\text { repetition Social } \\
\text { adjustment } \\
\text { Depression GHQ } \\
\text { Target problems } \\
\text { Attitudes to treatment } \\
\text { Assessed pre-treatment } \\
\text { and at } 2,4,9 \text { months }\end{array}$ & $\begin{array}{l}\text { No overall differences } \\
\text { between two groups } \\
2 \text { sub-groups } \\
\text { benefited from } \\
\text { out-patient counselling } \\
\text { rather than GP } \\
\text { care: women and } \\
\text { those with relationship } \\
\text { problems }\end{array}$ & $\begin{array}{l}\text { Only } 80 \text { of } 654 \\
\text { over-dose patients } \\
\text { were considered eligible, } \\
\text { or available for the study } \\
\text { - questions } \\
\text { generalisability of } \\
\text { interventions }\end{array}$ \\
\hline
\end{tabular}


Table 1 (Continued)

\begin{tabular}{|c|c|c|c|c|c|c|}
\hline Authors & Design & Treatment & Clients & Assessment & Findings & Comments \\
\hline $\begin{array}{l}\text { Moller } \\
(1989)\end{array}$ & $\begin{array}{l}\text { RCT } \\
\text { Standard care - } \\
\text { psychodynamic approach } \\
\text { as inpatient }(n=85) \\
\text { vs Standard care with } \\
\text { short term } \\
\text { psychotherapy as } \\
\text { outpatient } \\
(n=68)\end{array}$ & $\begin{array}{l}\text { Psychotherapy offered } \\
\text { to experimental } \\
\text { group limited to } \\
12 \text { sessions within } \\
3 \text { months of discharge }\end{array}$ & $\begin{array}{l}\text { Self-poisoning } \\
\text { clients admitted to } \\
\text { specialist unit in } \\
\text { Germany }\end{array}$ & $\begin{array}{l}\text { Social functioning } \\
\text { Mental state assessment } \\
\text { Self-rating of depression } \\
\text { Inpatient bed-use } \\
\text { Suicidal behaviour } \\
\text { Pre-treatment, } \\
\text { following inpatient } \\
\text { stay and one year } \\
\text { follow-up }\end{array}$ & $\begin{array}{l}\text { E group significantly } \\
\text { worse on suicidal } \\
\text { behaviour and slightly } \\
\text { worse on hospitalisation } \\
\text { and ability to work } \\
\text { No other differences }\end{array}$ & $\begin{array}{l}\text { Impact of inpatient } \\
\text { treatment accounted } \\
\text { for most of improvements } \\
\text { No support for } \\
\text { psychodynamic approach }\end{array}$ \\
\hline $\begin{array}{l}\text { Lineham et al. } \\
\text { (1991) }\end{array}$ & $\begin{array}{l}\text { RCT Treatment } \\
\text { as usual }(n=22) \text { vs } \\
\text { Cognitive-behavioural } \\
\text { treatment }(n=22)\end{array}$ & $\begin{array}{l}\text { Dialectical behaviour } \\
\text { therapy (CBT and } \\
\text { supportive approach) } \\
\text { One hour per week } \\
\text { for one year }\end{array}$ & $\begin{array}{l}\text { Women with } 2 \text { or } \\
\text { more DSH attempts } \\
\text { in past } 5 \text { years } \\
\text { and DSM III } \\
\text { diagnosis of } \\
\text { borderline } \\
\text { personality disorder }\end{array}$ & $\begin{array}{l}\text { Depression } \\
\text { Hopelessness } \\
\text { Suicidal behaviour } \\
\text { Service use } \\
\text { Survival and coping } \\
\text { skills Pre-treatment, } \\
4,8 \text { and } 12 \text { months }\end{array}$ & $\begin{array}{l}\text { E group had fewer } \\
\text { incidences of, } \\
\text { and less severe DSH } \\
\text { Fewer inpatient days } \\
\text { More likely to stay in } \\
\text { therapy } \\
\text { No other differences }\end{array}$ & $\begin{array}{l}\text { Very disabled } \\
\text { client group - questions } \\
\text { about generalizability } \\
\text { Needs experienced } \\
\text { therapists Expensive } \\
\text { intervention Longer term } \\
\text { effectiveness not clear }\end{array}$ \\
\hline $\begin{array}{l}\text { Salkovskis et al. } \\
\text { (1990) }\end{array}$ & $\begin{array}{l}\text { RCT Treatment } \\
\text { as usual }(n=8) \text { vs } \\
\text { Cognitive behavioural } \\
\text { problem solving } \\
\text { treatment }(n=12)\end{array}$ & $\begin{array}{l}\text { Cognitive behavioural } \\
\text { problem solving } \\
\text { treatment provided } \\
\text { by one nurse in } \\
\text { patient's homes }\end{array}$ & $\begin{array}{l}\text { DSH patients in } \\
\text { A\&E with high } \\
\text { risk of repeat attempt, } \\
\text { i.e. } 2 \text { or more of } \\
\text { following: } \\
2+\text { previous attempts, } \\
\text { past psychiatric } \\
\text { treatment, alcohol } \\
\text { problems, living alone, } \\
\text { diagnosis of sociopathy }\end{array}$ & $\begin{array}{l}\text { Suicidal ideation } \\
\text { Personal problems } \\
\text { ranked and scaled } \\
\text { Suicidal behaviour } \\
\text { Service use }\end{array}$ & $\begin{array}{l}\text { E group improved } \\
\text { on depression, } \\
\text { hopelessness, } \\
\text { suicidal ideation, } \\
\text { target problems and } \\
\text { short-term } \\
\text { reduction in } \\
\text { repeat DSH }\end{array}$ & $\begin{array}{l}\text { Small numbers More } \\
\text { women in E group } \\
\text { One nurse undertook } \\
\text { all treatment } \\
\text { High risk clients } \\
\text { No drop-outs } \\
\text { from treatment - ? } \\
\text { associated with } \\
\text { home visits }\end{array}$ \\
\hline
\end{tabular}

Notes

RCT, Randomized controlled trial.

C, Control.

E, Experimental.

GHQ, General Health Questionnaire.

NS, Not Significant. 
- All patients presenting with DSH need a full assessment to determine the level of risk to themselves and others (particularly those dependent upon them) and to agree the most appropriate course of action.

- Patients meeting criteria for high risk of repeat self-harm are likely to improve more than less severely impaired patients and might be targeted for specific therapy.

- Therapy should be based on a problem-solving approach. Psychodynamic approaches are not effective. Principles of problem-solving approaches are summarized in Figure 2.

- Family members or important others should be included in therapy where they are judged to have a significant relationship with the patient.

- Compliance with therapy is higher when patients are seen in their own homes.

- Compliance with therapy is associated with improvement. Those least likely to attend out-patient appointments are those with relationship problems and in lower social classes. These groups might benefit from targeted home care.

- Women and people with relationship problems appear to benefit most from supportive problem-solving counselling. Less is known about the approach most beneficial for men.

- A written and verbal offer of open access to help and, if requested, admission unless DSH has been repeated, appears to reduce repeat episodes. Details of this (Green Card) system are given in Williams \& Morgan (1994).

Figure 1 Implications of intervention studies for practice.

1 Explicit recognition and admission that a problem exists.

2 Identification of underlying problems.

3 Generation of possible solutions (or alternative solutions to suicide/DSH).

4 Implementation of solutions (or of one feasible solution at a time).

5 Assessing the outcome.

Figure 2 Principles of problem-solving approaches.

concluded that a problem solving intervention is probably better than no intervention at all, particularly for people at high risk of repeating DSH, women and people with relationship problems. The aim of this approach (see Figure 2) is to identify life situations which provoke suicidal behaviour and to minimize the negative impact of hopelessness on current and future coping attempts. It seeks to increase the individual's ability to solve problems and challenge specific cognitive distortions. It also provides a framework for the development of a therapeutic relationship, it can be used with couples, the family or in group settings, it should involve other resources where appropriate to solve social, financial problems for example, and should always be based on principles of good practice such as a non-judgmental attitude and active listening.

\section{PEOPLE WITH KNOWN PSYCHIATRIC MORBIDITY}

\section{Epidemiology}

Patients with known mental health problems are frequently referred to $\mathrm{A} \& \mathrm{E}$ departments for urgent assessment or emergency treatment. Indeed in many areas this is the only available service for crisis intervention at weekends and at night. Hawton \& Fagg's (1988) study discussed above in relation to DSH indicates the importance of psychiatric morbidity in predicting suicide. Studies which have scrutinized the histories of people who have committed suicide indicate that over $90 \%$ have been judged to have some form of psychiatric illness (Barraclough et al., 1974; Rich et al., 1986). Appleby (1992) reviews the clinical characteristics of completed suicide amongst people with psychiatric diagnoses and concludes that schizophrenia is the highest risk diagnosis, with young male patients with low mood, hopelessness and an awareness of the effect of their illness being particularly at risk, whilst young male alcoholics with a short illness history, previous attempts, loss of close relationship and a history of DSH are also a high-risk group.

\section{The role of $A \mathbb{E} E$ with people who have serious mental health problems}

There is little research concerning the management of people with serious mental health problems in A\&E. Indeed, research into DSH has generally, by definition, excluded those at high risk or with severe mental health problems. Since these people often present in A\&E following a suicide attempt and/or at a time when their mental state has deteriorated and/or when their support network has broken down, they present a clear risk of suicide at this time. Drawing on the findings of a national survey of psychiatric emergency provision carried out in 1991, Johnson \& Thornicroft (1994) give a list of suggestions for an adequate A\&E service for the management of psychiatric emergencies. These include adequate 
training and supervision for staff in A\&E; multidisciplinary teamwork; adequate settings for assessment and waiting in A\&E; mental health services which are easily accessed by patients with mental health problems; and effective screening for physical disorder.

Johnson \& Thornicroft (1994) point out that any substantial improvement in the success of A\&E departments in the prevention of suicide is likely to rest on the development of assertive strategies for following up people with serious mental health problems. At present the emphasis is on managing short-term risk. However, patients are frequently not engaged in any long-term care or rehabilitation and where referral for out-patient care is made, efforts are rarely made to check whether this is taken up. Discharge planning and clearly defined and communicated community support within psychiatric services is essential in ensuring that those most vulnerable to suicide receive adequate care in the community and have an identified worker to contact if and when they present in $\mathrm{A} \& \mathrm{E}$.

\section{PATIENTS PRESENTING IN A\&E WITH PHYSICAL PROBLEMS}

Psychiatric morbidity is high amongst all attendees in casualty departments even where their presenting complaints are ostensibly physical. Bell et al. (1991) found that 28 of 120 daytime attendees with physical complaints at a central London casualty department reached 'caseness' on the General Health Questionnaire (GHQ: Goldberg \& Hillier, 1979) and a diagnosis could be made for 24 of these people. Similar findings have been reported in a study comparing populations of $A \& E$ attendees in the UK and the US (Bassuk et al., 1983).

Atha (1994) reported that when patients with acute psychosis, drug abuse, and parasuicide attempts were excluded, $25 \%$ of the patients attending Leeds General Hospital A\&E department were rated as having psychological disorders on the Hospital Anxiety and Depression Scale (HAD: Zigmond \& Snaith, 1983) or GHQ. Although the majority of these patients attended $A \& E$ with minor physical injuries, their psychological problems did not disappear with their physical injuries: $26 \%$ continued to have psychological disorders at one month follow-up. This group of patients were found to be agreeable to help with their psychological difficulties. They also agreed that they had difficulty in coping with everyday problems and they attended casualty departments significantly more frequently than patients who did not have psychological disorder. This suggests not only that people with psychological difficulties can be identified through the use of standard- ized measures, but that they might be amenable to a problem-solving intervention which might reduce their attendance in casualty departments. However, it is not clear to what extent this group present a risk of suicide: the rate of suicide is likely to be so low amongst this group that any intervention would not have a significant suicide prevention effect. Again, the importance of thorough assessment of all people attending A\&E is indicated, so that psychological disturbance and suicidal ideas and intent are identified and appropriate follow-up care organized.

A group of patients attending casualty with physical illness who present a high risk of suicide are those with chronic and/or terminal physical illness (Whitlock, 1986). These people also have a higher than expected rate of psychiatric disorder, particularly depression (Mayou \& Hawton, 1986). This again emphasizes the need for thorough assessment and for all professionals working in $\mathrm{A} \& \mathrm{E}$ to be trained in the detection of depression and suicide risk.

\section{THE ROLE OF A 'SUICIDE PREVENTION NURSE' IN A\&E}

Several reports have described the development of specialist nursing posts within A\&E departments (Minghella, 1989; Salkovskis et al., 1990; Wishart et al., 1993; Atha, 1994). As in the literature as a whole, the targeted client group for these nurses is clients who have deliberately harmed themselves rather than all those people presenting in $\mathrm{A} \& \mathrm{E}$ who are at risk of suicide. Their role has included the assessment of all DSH patients in A\&E; provision of problem-solving counselling interventions for DSH patients - if necessary in their own homes and involving family members; ensuring appropriate referral to relevant agencies; following up patients who discharge themselves; and establishing close links with $\mathrm{A} \& \mathrm{E}$ staff, medical wards where patients are admitted, and appropriate psychiatric services. Only one of these services has been fully evaluated (Salkovskis et al., 1990), and the results of this study are discussed above.

\section{Conclusion}

The prevention of suicide has received unprecedented attention over the past 5 years with the publication of international guidelines and UK national targets. There is little evidence that these targets can be met as no suicide prevention strategies have been conclusively demonstrated to be effective. However, increasing understanding of risk criteria is helping to refine the process of risk assessment, and there is some evidence that targeted problem-solving interventions can help specific groups of patients. Obviously 
health care alone has a limited role in the prevention of suicide: broad social factors are at least as important, as is access to a means of committing suicide. Yet given the high numbers of suicides amongst people who have been in recent contact with health services, and the association between suicide and psychiatric illness, physical ill-health and previous deliberate self-harm, health services have an important role to play. In any local health service, it is therefore vital to have an overall suicide prevention strategy which involves primary and secondary services, general and mental health services, social services and voluntary services. $A \& E$ departments have an important part to play in this strategy: they work at the interface of all the other components of a local service and they are an important point of access for people at particular risk of suicide. This review has considered the evidence available on the assessment and management of suicide in A\&E departments as just one part of a local suicide prevention strategy.

The literature on suicide and DSH delineates three groups of patients attending $\mathrm{A} \& \mathrm{E}$ who are at risk of suicide. For each of these groups, there are clearly a number of strategies that might usefully be implemented in $\mathrm{A} \& \mathrm{E}$ departments to reduce/prevent suicide. Although it is useful to consider these groups separately in order to understand the types of interventions likely to be most successful, there is a great deal of overlap in their needs. The employment of one person will not solve all the problems that exist and one person cannot be expected to co-ordinate all the systems necessary to create and support a high quality service with adequately trained staff and careful clinical supervision. In order to provide a safe and effective environment in which patients at risk of suicide can be fully assessed and appropriately managed, there needs to be action at the levels of purchasing and service planning, including the interface between different agencies and service providers; the multidisciplinary team in $\mathrm{A} \& \mathrm{E}$, and individual suicide prevention workers within A\&E (see Repper, 1997).

Although there are few reports of nurses working in A\&E to prevent suicide, those that do exist describe primarily clinical roles. This review suggests, however, that in view of the poor information and communication systems; lack of knowledge about suicide; negative attitudes towards people who self-harm; unsuitable environment for sensitive discussion in $\mathrm{A} \& \mathrm{E}$; inadequate clinical supervision and scarce problem solving skills amongst $\mathrm{A} \& \mathrm{E}$ staff, the role of the 'suicide prevention nurse' in $\mathrm{A} \& \mathrm{E}$ will need to include support, training and development as well as time limited therapy with a carefully defined group of patients at particular risk. Therefore, the role might usefully include the following components:
- Involvement in development, implementation and review of overall systems of working with patients at risk of suicide in A\&E.

- Development of close working relationship with all members of the $\mathrm{A} \& \mathrm{E}$ multidisciplinary team and medical wards to which patients are admitted, so that the role is widely understood and referrals are made/ information is conveyed to specialist nurse as appropriate.

- Full assessment of all DSH patients as soon as possible following presentation in A\&E. This may take place in $\mathrm{A} \& \mathrm{E}$, on a medical ward, or in the patient's own home.

- Referral to appropriate services as necessary. All patients in present or previous contact with psychiatric services to have written referral back to their psychiatrist or key worker for assessment and re-assessment. Where the key worker is known, responsibility for follow-up can be left with them. Where follow-up takes the form of an out-patient appointment, the specialist nurse is responsible for checking up on attendance.

- Time-limited, problem-solving therapy (following the model described in Salkovskis et al., 1990) for patients with clear indication of risk of repeat DSH.

- Problem-solving/supportive counselling for patients identified by A\&E staff as having psychological problems, possibly targeting those with chronic and disabling physical illness.

- Communication of all treatment and follow-up to the general practitioner and other service providers involved.

- Involvement in education and training of A\&E staff and staff on medical wards where DSH patients are admitted - including challenging negative attitudes.

- Involvement in clinical supervision of staff undertaking suicide risk assessment.

- Involvement in compiling local data base of resources which might be useful for patients at risk of suicide.

\section{References}

Anglia Polytechnic University Faculty of Health and Social Work in Partnership with NHS Management Executive (1994) National clinical guidelines for multi-disciplinary staff working with suicidal and deliberate self-harming patients in Accident and Emergency Departments. Anglia Polytechnic University, Essex.

Appleby L. (1992) Suicide in psychiatric patients: risk and prevention. British Fournal of Psychiatry 161, 749-758.

Atha C. (1994) The role of the CPN with clients who deliberately harm themselves. In: Community Psychiatric Nursing: a Research Perspective (ed. Brooker C.). Chapman \& Hall, London.

Barraclough B., Bunch J., Nelson B. \& Sainsbury P. (1974) A hundred cases of suicide: clinical aspects. British fournal of Psychiatry 161, 749-758. 
Bassuk E., Winter R. \& Aspler R. (1983) Cross cultural comparison of British and American psychiatric emergencies. American Fournal of Psychiatry 140, 180-184.

Bell G., Reinstein D., Rajiyah G. \& Rosser R. (1991) Psychiatric screening of admissions to an accident and emergency ward. British Fournal of Psychiatry 158, 554-557.

Buglass D. \& Horton J. (1974) A Scale for predicting subsequent suicidal behaviour. British fournal of Psychiatry 124, 573-578.

Charlton J., Kelly S., Dunnell K., Evans B., Jenkins R. \& Wallis R. (1992) Trends in suicide deaths in England and Wales. Population Trends 69, 10-16.

Chowdhury N., Hicks R.C. \& Kreitman N. (1973) Evaluation of an aftercare service for parasuicide (attempted suicide) patients. Social Psychiatry 8, 67-81.

Department of Health (1992) The Health of the Nation. HMSO, London.

Gardner R., Hanka R. \& Roberts S. (1982) Psychological and social evaluation in cases of deliberate self-poisoning seen in an accident department. British Medical fournal 284, 491-493.

Gibbons J.S., Butler P., Urwin P. \& Gibbons J.L. (1978) Evaluation of social work service for self-poisoning patients. British Fournal of Psychiatry 133, 111-118.

Goh S., Salmons P. \& Whittington R. (1989) Suicide in psychiatric hospitals. British Fournal of Psychiatry 154, 247-250.

Goldberg D. \& Hillier V. (1979) A scaled version of the general health questionnaire. Psychological Medicine 11, 169-177.

Gunnell D. (1994a) The Potential for Preventing Suicide. a Reviem of the Literature on the Effectiveness of Interventions Aimed at Preventing Suicide. Health Care Evaluation unit, University of Bristol.

Hawton K., Bancroft J. \& Catalan J. (1981) Domicilliary and outpatient treatment of self-poisoning patients by medical and nonmedical staff. Psychological Medicine 11, 169-177.

Hawton K. \& Fagg J. (1988) Suicide and other causes of death, following attempted suicide. British Fournal of Psychiatry 152, 359-366.

Hawton K. \& Fagg J. (1992) Trends in deliberate self-poisoning and self-injury in Oxford, 1976-90. British Medical fournal 304, 1409-1411.

Hawton K., McKeown S., Day A., Martin P., O’Connor M. \& Yule J. (1987) Evaluation of out-patient counselling compared with general practitioner care following overdoses. Psychological Medicine 17, 751-761.

Johnson S. \& Thornicroft G. (1991) Psychiatric Emergency Services in England and Wales. Report of a study commissioned by the DoH Department of Health, HMSO, London.

Johnson S. \& Thornicroft G. (1994) General medical services Accident and Emergency Departments. In: The Prevention of Suicide. (eds Jenkins R., Griffiths S., Wylie I., Hawton K., Morgan G. \& Tyree A.).HMSO, London.

Lineham M., Armstrong H., Suarez A., Allmon D. \& Heard H. (1991) Cognitive-behavioural treatment of chronically parasuicidal borderline patients. Archives of General Psychiatry 48, 10601064.

Mayou R. \& Hawton K. (1986) Psychiatric disorder in the general hospital. British Fournal of Psychiatry 140, 179-190.

Minghella E. (1989) The role of the nurse in the management of parasuicide in the community. In: Directions in Nursing Research (eds Wilson Barnett J. \& Robinson S.). Churchill Livingstone, Edinburgh.
Moller H.J. (1989) Efficacy of different strategies of aftercare for patients who have attempted suicide. Fournal of the Royal College of Medicine 82, 643-647.

Morgan G. (1994) Assessment of risk. In: The Prevention of Suicide (eds Jenkins R., Griffiths S., Wylie I., Hawton K., Morgan G. \& Tyree A.). HMSO, London.

Morgan G. \& Evans M. (1995) How negative are we to suicide prevention? Proceedings of the Royal Society of Medicine conference, September 1994.

Morgan H., Jones E. \& Owen J. (1993) Secondary prevention of non-fatal deliberate self-harm: the green-card study. British Journal of Psychiatry 163, 111-112.

Morgan G. \& Priest J. (1991) Suicide and other unexpected deaths among psychiatric patients. British Fournal of Psychiatry 158, 368374.

Nordentoft M., Breum L., Nordestgaard A., Hunding A. \& Laursen Bjaeldager P. (1993) High mortality by natural and unnatural causes: a 10 year follow-up study of patients admitted to a selfpoisoning centre after suicide attempts. British Medical Fournal 306, 1637-1641.

Pallis D., Barraclough B., Levy A., Jenkins J. \& Sainsbury P. (1982) Estimating suicide risk amongst attempted suicides 1: the development of new clinical scales. British Fournal of Psychiatry 141, 37-44.

Pierce D. (1986) Deliberate self-harm: how do patients view their treatment? British Fournal of Psychiatry 149, 624-626.

Pokorney A. (1983) Prediction of suicide in psychiatric patients. Archives of General Psychiatry 40, 249-257.

Ramon S., Bancroft J. \& Skrimstone A. (1975) Attitudes to self poisoning among physicians and nurses in a general hospital. British Fournal of Psychiatry 127, 257-264.

Repper J. (1997) A reviem of the literature on the prevention of suicide through interventions in Accident and Emergency Departments. Report for Community Health Sheffield NHS Trust. ScHARR, University of Sheffield.

Rice K. \& Donnelly P. (1991) Use of rating scales by consultant psychiatrists. Psychiatric Bulletin 15, 114.

Rich C., Young D. \& Fowler R. (1986) San Diego suicide study: young vs. old subjects. Archives of General Psychiatry 43, 577582.

Salkovskis P.M., Atha C. \& Storer D. (1990) Cognitive-behavioural problem solving in the treatment of patients who repeatedly attempt suicide: a controlled trial. British Fournal of Psychiatry 157, 871-876.

Vassilas C. \& Morgan H. (1993) General practitioners' contacts with victims of suicide. British Medical Fournal 307, 300-301.

Whitlock F. (1986) Suicide and physical illness. In: Suicide (ed. Roy A.). Williams \& Williams, Baltimore, MD.

Williams R. \& Morgan G. (1994) (eds) NHS Health Advisory Service Thematic Reviem: Suicide Prevention, The Challenge Confronted. HMSO, London.

Wishart J.A., Knight S. \& Gehlaar E. (1993) Deliberate self-harm: an audit of a service to patients. International fournal of Health Care Quality Assurance 6, 4-8.

World Health Organisation (1982) Changing patterns in suicide behaviour. Report of a WHO working group. Copenhagen.

Zigmond A. \& Snaith R. (1983) The hospital anxiety and depression scale. Acta Psychiatrica Scandinavica 67, 361-370. 